Review Article

\title{
Therapeutic Implications of Black Seed and Its Constituent Thymoquinone in the Prevention of Cancer through Inactivation and Activation of Molecular Pathways
}

\author{
Arshad H. Rahmani, ${ }^{1}$ Mohammad A. Alzohairy, ${ }^{1}$ Masood A. Khan, ${ }^{2}$ and Salah M. Aly ${ }^{1,3}$ \\ ${ }^{1}$ Department of Medical Laboratories, College of Applied Medical Sciences, Qassim University, Buraydah, Saudi Arabia \\ ${ }^{2}$ Basic Health Science, College of Applied Medical Sciences, Qassim University, Buraydah, Saudi Arabia \\ ${ }^{3}$ Department of Pathology, Faculty of Veterinary Medicine, Suez Canal University, Ismailia, Egypt \\ Correspondence should be addressed to Arshad H. Rahmani; rehmani.arshad@gmail.com
}

Received 5 January 2014; Revised 26 February 2014; Accepted 16 April 2014; Published 18 May 2014

Academic Editor: Shrikant Anant

Copyright (C) 2014 Arshad H. Rahmani et al. This is an open access article distributed under the Creative Commons Attribution License, which permits unrestricted use, distribution, and reproduction in any medium, provided the original work is properly cited.

\begin{abstract}
The cancer is probably the most dreaded disease in both men and women and also major health problem worldwide. Despite its high prevalence, the exact molecular mechanisms of the development and progression are not fully understood. The current chemotherapy/radiotherapy regime used to treat cancer shows adverse side effect and may alter gene functions. Natural products are generally safe, effective, and less expensive substitutes of anticancer chemotherapeutics. Based on previous studies of their potential therapeutic uses, Nigella sativa and its constituents may be proved as good therapeutic options in the prevention of cancer. Black seeds are used as staple food in the Middle Eastern Countries for thousands of years and also in the treatment of diseases. Earlier studies have shown that $N$. sativa and its constituent thymoquinone (TQ) have important roles in the prevention and treatment of cancer by modulating cell signaling pathways. In this review, we summarize the role of N. sativa and its constituents TQ in the prevention of cancer through the activation or inactivation of molecular cell signaling pathways.
\end{abstract}

\section{Introduction}

The cancer is probably the most dreaded disease of mankind and a major health problem worldwide. The exact cause of cancer development and progression is not completely known, but it is considered to be due to alteration of genetic and epigenetic pathways. Altered function/expression of various genes such as tumor suppressor genes, apoptotic genes, oncogene, and other genes has been noticed in various tumors [1-7]. Current modes of treatment based on synthetic drugs/chemotherapy have limited potential, because they are toxic and expensive and also alter the functioning of the cell signaling pathways. Natural drugs which are safe, affordable, and effective are needed to control the cancer development and progression. Natural products have been used for thousands of years in the management of several diseases including various types of cancer. They have therapeutic implications in various cancers via inhibiting angiogenesis process and activation of tumor suppressor gene and also show an important role in the modulation of other several activities. Earlier reports have shown that diet rich in fruits, vegetables, cereal grains, and spices decreases the risk of cancer growth and its metastasis [8-10]. Most of the drugs in chemotherapy act as monotarget molecules, whereas medicinal plants have multitarget molecules that can regulate the cancer growth and its progression. Nigella sativa has many beneficial constituents which can be used in the treatment of various diseases (Figure 1). Nigella sativa is commonly used medicinal plant which has been used for thousands of years in traditional system of medicine for example, Ayurveda, Unani, Arabic and Chinese medicine. It is claim that Prophet Muhammad (PBUH) said "Use Black seed regularly, since it is a cure for every disease except death" [11].

It is also known that herbal constituents may play an important role in cancer cure through antitumor activity or by suppressing bioactivation of carcinogen [12]. There 


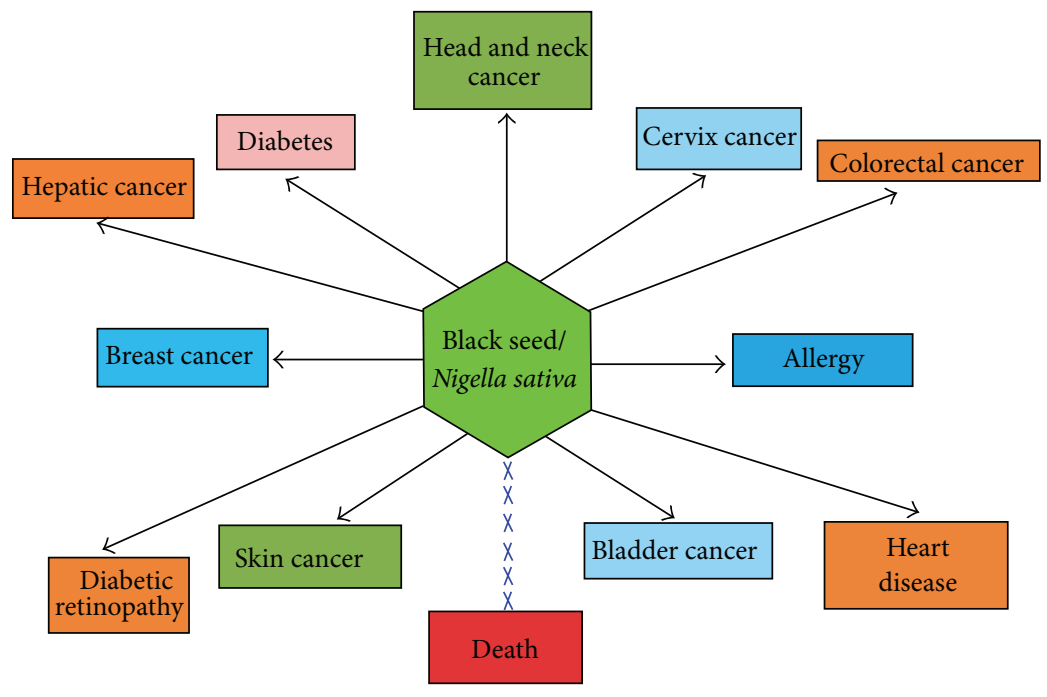

FIGURE 1: N. sativa shows an important role in the management of various diseases.

are numerous medicinal plants/products which are beneficial for health and also have antitumor, antimicrobial, antibacterial, and antioxidant nature [13-19]. An important study summarized the importance of black seed oil and its active compound TQ in the diseases management including cancer [20]. TQ is considered as potent anticarcinogenic and antimutagenic agent $[21,22]$ and aqueous and alcohol extracts of $N$. sativa were found to be effective in vitro in inactivating MCF-7 breast cancer cells [23]. In this review, we summarize the role of $N$. sativa and its constituent TQ in the prevention of cancer through activation or inactivation of various genetic pathways.

\section{Active Ingredients and Chemical Structure of $N$. sativa}

Numerous active compounds were isolated and identified in $N$. sativa (Figure 2). N. sativa and its constituents showed therapeutic effects by modulating various cell signaling activities. Chief constituents/ingredients of $N$. sativa are thymoquinone (TQ), dithymoquinone (DTQ), thymohydroquinone (THQ), and thymol (THY) [24]; p-cymene, 4-terpineol, and t-anethol. $N$. sativa seeds contain other ingredients as well, such as carbohydrates, fats, vitamins, mineral elements, proteins, and essential amino acids [2428]. Black seed also contain nigellidine,nigellimine,nigellcine [29], saponine and water soluble triterpene [25].

\section{Mechanism of Action of Thymoquinone in Cancer Prevention}

Cancer is a multifactorial disease, including alteration in genetic pathways [30]. Numerous studies have shown that TQ has therapeutic potential in the health management/human health as well as in the prevention of cancer via modulation of genetic cascades. TQ shows a critical role in controlling cancer via the activation of tumor suppressor gene, phase II gene/enzymes, and peroxisome proliferatoractivated receptors (PPARs), inactivation of angiogenesis and anti-inflammatory gene, and induction of apoptosis. An important finding in this regard proved that TQ showed anticancer effects and regulated apoptosis in doxorubicinresistant human breast cancer cells (MCF-7/DOX cells) [31]. That TQ induces apoptosis in doxorubicin-resistant breast cancer cells via upregulation of PTEN at the transcription level, and upregulated PTEN plays a significant task in inhibition of phosphatidylinositol-3 kinase/Akt pathway and induces $\mathrm{p} 53$ and $\mathrm{p} 21$ protein expression [31]. TQ also modulates various pathways such as inhibition of phase I enzymes (cytochrome p450) and activation of phase 2 detoxifying enzymes (glutathione transferase and N-acetyl transferase), inhibition of multiple signal transduction pathways that trigger cell proliferation, and invasion and activation of PPARs. TQ inhibits NF- $\kappa$ B activation with resultant downregulation of multiple inflammatory genes. A recent study reported that TQ intervenes with TNF and NF-kappa-B signaling during TQ-mediated induction of apoptosis in cancer cells [32]. TQ finally acts as multiple target modulator in the cancer control via modulation of genetic pathways (Figure 3 ).

\section{The Implications of $N$. sativa in Cancer Therapy}

Several active constituents are present in $N$. sativa and these constituents play a role in tumor prevention. The seeds contain both fixed and essential oils, proteins, alkaloids, and saponin [33]. Earlier studies have reported the precise mechanism of tumor inhibition by $N$. sativa volatile oil. For instance, thymoquinone was found to have antioxidant effects in animal models [34-36]. Black seed and its chief constituents TQ shows therapeutics role in diseases control including cancers such as pancreatic, osteosarcoma, bladder, breast, colon, skin and lung and other diseases [37-44]. Earlier investigators showed that oral administration of TQ was 
<smiles>CC1=CC(=O)C(C(C)C)=CC1=O</smiles>

Thymoquinone<smiles>Cc1cc(O)c(C(C)C)cc1O</smiles>

Thymohydroquinone<smiles>CC(C)C1=CC(=O)C2C(C1=O)[C@]1(C)C(=O)C=C(C(C)C)C(=O)[C@]21C</smiles>

Dithymoquinone<smiles>Cc1ccc(C(C)C)cc1</smiles>

p-Cymene

Figure 2: Chemical structure of active ingredients of Nigella sativa.

Black seed/
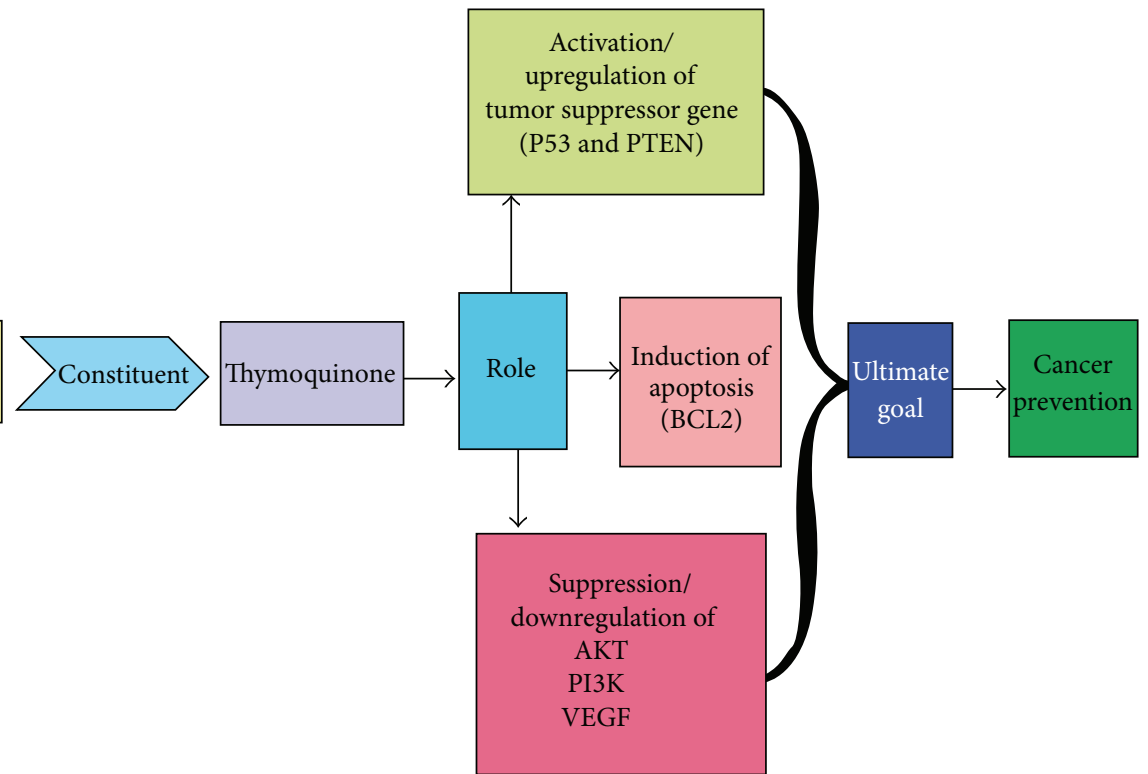

FIGURE 3: N. sativa shows a vital effect in the prevention of cancer through upregulation of tumor suppressor gene and inhibition of VEGF, Akt/PI3K pathways.

effective in increasing the activities of quinine reductase and glutathione transferase and suggested that TQ may be a useful drug in treating chemical carcinogenesis and toxicity in liver cancer [45]. An important study showed that black seed preparations have a cancer chemopreventive ability and also reduce/suppress the toxicity of standard antineoplastic drugs [46]. Another experimental study reported that black seed extract plays an important role in the prevention of skin carcinogenesis via inhibition of the two-stage initiationpromotion [47]. TQ shows various biological activities via modulation of antineoplastic, antioxidant, antitumor, and antimicrobial effects [48-52]. TQ plays a role in the prevention of cancer via modulation of various genes including tumor suppressor genes, apoptotic genes, hormonal receptor 
genes, and detoxifying genes. The study proposed the detailed mechanism of action of genes in the management of cancer is described as the following.

4.1. Effect of Thymoquinone on Tumor Suppressor Gene. Mutation or alteration of tumor suppressor genes contributes to the development of cancer by inactivating the inhibitory functions. $N$. sativa and its constituents play a role in the prevention of cancer via the activation of tumor suppressor gene. PTEN is a multifunctional phosphatase, whose major substrate is phosphatidylinositol-3,4,5-trisphosphate (PIP3) [53] and lipid phospahatse activity of pten play an important role in dephosphorylation of PIP3 and also inhibit the Akt/PI3K pathways. Altered expression of PTEN has been noticed in cancer [54]. However, PI3K/Akt inactivation and upregulation of PTEN are of prime importance in the cancer prevention. An important study showed time-dependent increase of PTEN in MCF-7/DOX cells and it was observed that TQ treatment induced an increase in PTEN mRNA by 1.8-, 2.0-, 3.8-, 5.9-, and 7.9-fold after 1, 2, 4, 8, and 24 hours, respectively [31]. TQ also plays a significant role in the modulation of other tumor suppressor genes such as p53, P21, and $\mathrm{p} 27$.

p53 is considered as guardian of genes and the function of p53 is altered in approximately $50 \%$ of cancers. Studies in the favor of TQ showed that TQ plays role in the modulation of p53 and finally suppresses the tumor development and progression. Earlier studies showed that TQ induces apoptosis through p53-dependent pathways in human colon cancer cells and animal models $[55,56]$ and apoptosis induction by TQ was associated with $2.5-4.5$-fold increase in mRNA expression of p53 and the downstream p53 target gene, p21WAF1 [55].

P21WAF1/CIP1 is a cyclin-dependent kinase (cdk) inhibitor and is one of the key mediators of p53-dependent cell cycle arrest after DNA damage [57, 58]. A finding showed that TQ induces apoptosis via upregulation of PTEN at transcription level in doxorubicin-resistant breast cancer cells. Furthermore, upregulated PTEN inhibited the PI3K/Akt pathway and induced p53 and p21 protein expression [31]. In p53-null myeloplastic leukemia HL60 cells, thymoquinone induced apoptosis by activating caspase-3, caspase-8, and caspase-9 [59].

4.2. Regulation of Apoptosis and Necrosis by TQ. Any modifications/changes which occur in the normal process of apoptosis may increase cell survival and promote tumor development and progression $[60,61]$. Earlier investigators have shown that plants (Glycyrrhiza uralensis Fisch) may have chemopreventive effects against different types of cancer by modulating the expression of the Bcl-2/Bax apoptotic regulatory factors [62]. Another study showed Myristica fragrans Houtt induced apoptosis of Jurkat leukemia T cell line in mechanisms involving SIRT1 mRNA downregulation [63].

$N$. sativa plays a major role in anticipation of cancer via the induction of proapoptotic factors Bak/Bax or downregulation of antiapoptotic proteins $\mathrm{Bcl}-2$ and $\mathrm{Bcl}-\mathrm{xL}$ that cause the activation of caspase in cancer cell without alteration in normal cells. Nigella sativa and its constituents TQ showed vital effects as anticancer and also trigger apoptotic cell death in human colorectal cancer via a p53-dependent mechanism $[55,64]$. A study demonstrate that Thymoquinone(TQ) treatment shows the down-regulation of constitutive activation of AKT via generation of reactive oxygen species (ROS) and it also causes conformational changes in Bax protein [65]. TQ also causes apoptosis in HEp-2 human laryngeal carcinoma cells through activation of caspase- 3 and inhibitors of caspases significantly reduced the TQ-induced apoptosis [66]. This finding shows that TQ plays a role in the induction of apoptosis and also has a significant role in the regulation of the caspase pathways. A study has shown that TQ inhibits G1 phase of cell cycle by increasing the expression of the cyclin-dependent kinase inhibitor p16 and downregulating the cyclin D1 protein expression in papilloma cells [67].

Another important study showed that all anticanceractive derivatives of Thymoquinone shows a role in induction of apoptosis associated with DNA laddering, a decrease in mitochondrial membrane potential and also increase in reactive oxygen species [68]. TQ also exhibits the anticancer activity through the modulation of multiple molecular targets, including p53, p73, PTEN, STAT3, PPAR- $\gamma$, activation of caspases, and generation of ROS [69].

Necrosis appears to be the result of acute cellular dysfunction in response to severe stress condition or after exposure to toxic agents [70]. Oxidative stress is one of the most important factors that play a role in various types of pathogenesis. Our body has defense mechanism against adverse effects of free radicals. If any imbalance occurs between free radical production and antioxidative defense system, that cause damage to macromolecules (DNA and protein). The constituents from plants play an important role in neutralisation of the oxidative stress via antioxidant properties. TQ oral administration showed protective role in various organs against oxidative damage induced by free radical generating agents [71]. Furthermore, TQ constitutes strong antioxidant properties via the scavenging ability of different free radicals, its scavenging power being as effective as SOD against superoxide anions [72, 73]. Earlier report showed that TQ inhibited the expression of the inducible nitric oxide synthase (iNOS) and iNOS mRNA expression in rat lipopolysaccharide stimulated peritoneal macrophage cells [74]. TQ shows an important role in suppression of tumor necrosis factor. An important study in human chronic myeloid leukemia cells KBM-5 showed that thymoquinone (TQ) suppressed tumor necrosis factor-induced NF- $\kappa$ B activation in a dose- and time-dependent manner and also played a role in the inhibition of activation of NF- $\kappa \mathrm{B}$ that was induced by several carcinogens and inflammatory stimuli [75].

4.3. Effect of TQ on Angiogenesis. Angiogenesis is a complex process, which plays a role in various types of cancer [7679]. TQ inhibits angiogenesis by suppressing the activation of one of the important motifs of angiogenesis. Endothelial cell migration shows a critical effect in the angiogenesis and TQ 
inhibited HUVEC migration in a concentration-dependent manner [80].

An experimental study showed that serum levels of VEGF were significantly low in TQ-treated group compared to control group. However, this result indicates that TQ has potential or ability to suppress the VEGF productions and prevents the tumor growth through antitumor angiogenesis [81]. A finding on osteosarcoma showed antitumor and antiangiogenesis effects of TQ through the NF- $\kappa$ B pathway [82]. An important finding suggests that TQ increases the antiangiogenic activity by inhibiting HUVEC differentiation into tube-like structures [83].

Another study of TQ in the angiogenesis on human pancreatic cancer cell line PANC-1 showed that incubation of EPCs with TQ decreased the tube-forming capacity [84].

4.4. TQ-Induced Inhibition of COX. Cyclooxygenase (COX) is also known as prostaglandin (PG) $\mathrm{H}$ synthase and catalyses the stages of prostanoids synthesis [85]. There are two types of COX enzymes, COX1 and COX2. COX1 is expressed in almost all tissue is the inducible isoform, which is regulated by growth factors and cytokines [86] and is overexpressed in inflammatory conditions. The overexpression of COX2 was observed in a wide range of cancers such as lung, stomach, breast, and pancreatic cancer [87-90]. The overexpression of COX2 plays a vital role in the upregulation of angiogenesis by prostaglandin and also shows effect in apoptosis by increasing the resistance to apoptosis [91]. COX2 also shows the inhibition of clinical behavior of some tumors [92]. However, COX2 inhibition is a critical step in the prevention of cancer. The inhibitor of COX2 shows a significant effect on the inhibition of COX2 action and also shows side effect in the tissues. Therefore, natural product is good choice in the prevention of tumor development through the inhibition of COX2. TQ showed a critical effect on the inhibition of COX2 expression and prostaglandin production in a mouse model of allergic airway inflammation [93].

4.5. Effect of TQ on Nuclear Factor $-\kappa B(N F-\kappa B)$. NF- $\kappa B$ is a transcription factor belonging to the Rel family of proteins that are involved in regulation of various genes [94, 95]. There are numerous carcinogens playing a role in the activation of $\mathrm{NF}-\kappa \mathrm{B}$ [96-100]. However, the regulation of NF- $\kappa \mathrm{B}$ action is a key step towards the prevention of cancer development and progression. Although the exact mechanism of action of TQ is not fully understood, it might be due to TQ inducing oxygen reactive species through the PI3K/Akt and p38 kinase pathways [101]. The activation of NF- $\kappa \mathrm{B}$ has been noticed in various tumors [102-104]. A recent study reported that TQ intervenes in NF-kappa-B signaling during TQ-mediated induction of apoptosis in cancer cells [32]. Another report showed that TQ has strong anti-inflammatory activity in several PDA cell lines and demonstrates that TQ mediates its effects by reducing the activity and transcription of NF$\kappa \mathrm{B}$ [105]. Another finding in vitro showed that TQ inhibits tumor angiogenesis and tumor growth by suppressing NF$\kappa \mathrm{B}$ and its downstream molecules [82]. TQ has been shown to have antitumor effects on bladder cancer in both in vitro and in vivo models through the downregulations of NF$\kappa \mathrm{B}$ and its regulated molecules such as XIAP [106]. Recent studies reported that TQ significantly downregulates NF- $\kappa \mathrm{B}$ and MMP-9 in Panc-1 cells [107].

4.6. Effect of TQ on Androgen Receptor (AR). Androgen plays a crucial role in the growth, differentiation, and maintenance of prostate tissue and also shows the effect in prostate cancer [108]. Earlier investigators showed that Casodex (bicalutamide), a specific inhibitor of AR, blocks the ability of $G_{1}$ phase of AR-positive LNCaP prostate cancer cells to enter S phase [109-111].

Cytotoxic chemotherapy and radiotherapy are not very effective in survival benefit for patients with hormonerefractory prostate cancer. Although taxane drugs are helpful, they are not fully effective [112-115]. The presently used chemotherapy shows adverse effects and also alters the normal mechanism of action of genes. N. sativa is a good candidate for chemoprevention that inhibits AR signaling. An recent study on animal model showed that thymoquinone suppresses the expression of AR and E2F-1 necessary for proliferation and viability of androgen-sensitive as well as androgen-independent prostate cancer cells both in vitro and in vivo and, interestingly, produced no clear side effects [116].

4.7. Effect of TQ on Lipoxygenase Activity. The lipoxygenase is a family of nonheme iron-containing dioxygenases that catalyze the stereospecific oxygenation of the 5-, 12-, or 15carbon atoms of arachidonic acid [117-119]. The metabolism of arachidonic acid by the lipoxygenase (LOX) pathway generates eicosanoids and these factors show a critical role in the pathogenesis of different human diseases including cancer [120]. Earlier investigators have observed the upregulation of LOX in various types of cancers $[121,122]$. The inhibition of LOX in the prevention of cancer is one of the critical steps towards management of cancer. An important report suggested that COX2 may play an important role in pancreatic tumour development and therefore be a promising chemotherapeutic target for the treatment of pancreatic cancer [123]. N. sativa plays a role in the downregulation of LOX or inhibition of 5-lipoxygenase and leukotriene C4 synthase in human blood cells by TQ [124].

4.8. Effect of TQ on Signal Transducers and Activators of Transcription. Signal transducers and activators of transcription 3 (STAT3) are the members of the STAT family and play a role in the regulation of transcription [125]. Signal transducers and activators of transcription (STAT) are the part of the signal transduction pathway of many growth factors, cytokines and are activated by phosphorylation of tyrosine and serine residues by upstream kinases [126]. Numerous studies showed that TQ suppresses STAT-3 phosphorylation and the expression of its downstream signalling effectors Bcl2, Bcl-XL, cyclin D1, survivin, Mcl-1, and VEGF [127, 128].

4.9. Effect of TQ in Phase I and II Enzyme/Genes. Xenobiotics are chemicals in our environment and exposure to these chemicals causes cancer. When these chemicals enter into our 
body, the body metabolizes them via phase I (CYP450) and phase II (GST) gene/enzyme.

Cytochrome P450 (CYP) plays a role in the activation of carcinogens and glutathione S-transferase (GST) shows the effect in the deactivation of reactive metabolites/carcinogens. However, the regulation of theses enzymes is important in the prevention of cancer. Black seeds and their constituents show a vital role in the control of cancer via inactivation and activation of phase I and II genes (Figure 4). An important study showed that TQ significantly inhibited CYP2D6 and CYP3A4 mediated metabolism of DEX in human liver microsomes [129].

Oral administration of TQ is a promising prophylactic agent against chemical carcinogenesis and toxicity in liver tissues by increasing the activities of quinone reductase and glutathione transferase [130].

4.10. Effect of TQ in Peroxisome Proliferator-Activated Receptors (PPARs) Activation. Peroxisome proliferator-activated receptors (PPARs) are ligand-activated transcription factors $[131,132]$. PPAR plays a key role in tumor suppression and also induced apoptosis as well as antiproliferative effect in various cancer cell lines [133-138]. The upregulation of PPAR plays a role in the prevention of cancer by regulating various genetic pathways including apoptosis. Presently PPAR- $\gamma$ agonist is in use for the activation, but these agonists show the side effect. Natural products are the best remedy, as they are safe without any side effect. TQ plays a significant role in the regulation of PPAR- $\gamma$ without any alteration in tissues. A study of TQ activity showed that it acts as antitumor by modulation of PPAR- $\gamma$ activation [139].

\section{Toxicity of TQ}

Drugs used in the treatment of diseases were considered to be safe in doses pattern. Medicinal plants have important value in the health management because of their low toxicity. Numerous studies have been investigated to know the toxicological properties of TQ in vitro and in vivo [140-142]. The oral and intraperitoneal lethal dose (LD50) in animal models such as rats and mice has been successfully assigned by earlier researcher $[143,144]$. The safety, tolerability, and less toxicity of N. sativa at higher doses are established via human clinical trials. A study showed that TQ at the concentrations of 0 to $10 \mu \mathrm{M}$ was not cytotoxic to fibroblast-like synoviocytes [145]. Earlier study showed that Nigella sativa did not show any toxicity effect on liver and supplementations of Nigella sativa reduce the alanine aminotransferase (ALT) level and aspartate aminotransferase (AST) level treated rats compared to the control doses of rats [146]. Another study reported that $0.6 \mathrm{mg} / \mathrm{kg} /$ day oral dose of TQ is suitable for humans [145] and $0.05 \mathrm{mg} / \mathrm{kg} /$ day of Nigella sativa extract for postmenopausal women [147]. Another report showed that the LD50 of oral administration of TQ was $2.4 \mathrm{gm} / \mathrm{kg}(1.52-$ $3.77,95 \% \mathrm{CL}$ ). Numerous studies in the support of N. sativa have shown that no evidence of $N$. sativa fixed oil toxicity was observed, when administered in different doses up to $10 \mathrm{~mL} / \mathrm{kg}$ body wt., p.o. [148]. N. sativa and its seed powder did not show any toxic effects and were safe at very high doses $(28 \mathrm{gm} / \mathrm{kg}$ orally) and its oil was also safe at dose $(28.8 \mathrm{ml} / \mathrm{kg})$ in rabbits and rats respectively $[149,150]$.

\section{Role of Analogues of TQ in Cancer}

Several types of TQ derivatives have been synthesised and successfully tested in animal models with better efficiency. An important study in this prospective has synthesized twentyseven analogues of TQ by the modification at carbonyl and benzenoid sites and test was performed to check the biological activity against pancreatic cancer cell lines. Analogues such as TQ-2G, TQ-4Al, and TQ-5Al were found to be more effective than parental TQ in terms of inhibition of cell growth, induction of apoptosis, and modulation of transcription factor, NF- $\kappa \mathrm{B}$ [151]. An earlier study has conjugated TQ with fatty acids to enhance the membrane penetration capacity and antitumor activity $[69,152]$ and also terpene conjugated with TQ showed greater antitumor activities than the parental drug [153]. The triterpene betulinic acid conjugate of TQ also exhibits up to 200 -fold better activity in HL-60 leukemia cells as compared to the control [153].

A recent study showed that Poloxin, a synthetic derivative of thymoquinone play a role in the induction of mitotic arrest and prolongs the mitotic duration, accompanied by Plkl's (member of Polo-like kinases) mislocalization at kinetochores and centrosomes with reduced $\gamma$-tubulin [154]. Antiproliferative effect of various thymoquinone analogues was tested with six human cell lines and the lead compound, ON01910, blocked the cancer cells and, furthermore, molecule OC2-23 was ten times more effective than the lead compound, ON01910 [155]. The other derivatives of thymoquinone such as 4-acylhydrazones and 6-Alkyl were also tested for growth inhibition in human HL-60 leukemia, 518A2 melanoma, KB-V1/Vb1 cervix, and MCF-7/Topo breast carcinoma cells. Among them, 6-hencosahexaenyl conjugate showed the most active effect with IC50 values as low as $30 \mathrm{nmole} / \mathrm{mL}$ in MCF-7/Topo cells [156].

\section{Clinical Trials Based Study of N. sativa}

Diseases are caused due to multifactorial alteration, including changes in hormone receptor gene, angiogenesis process, tumor suppressor gene, and apoptosis cascade and metabolic process. Current modes of treatment based on synthetic drugs are effective; unfortunately they show the limitation as monotarget capability and adverse side effect. The drugs with multitargets potentiality are needed to control the diseases by modulating various genetic pathways. $N$. sativa shows therapeutic role in the management of diseases via multiple target activities in the clinical base study. Earlier investigators have shown that $N$. sativa and its constituents show vital effect in disease control without any toxic effect. A few studies have been performed on human to check the efficacy of TQ in disease management. The first study of TQ in human trial of advanced malignant cancer patients showed that treatment with TQ tolerated the drug at oral doses up to 


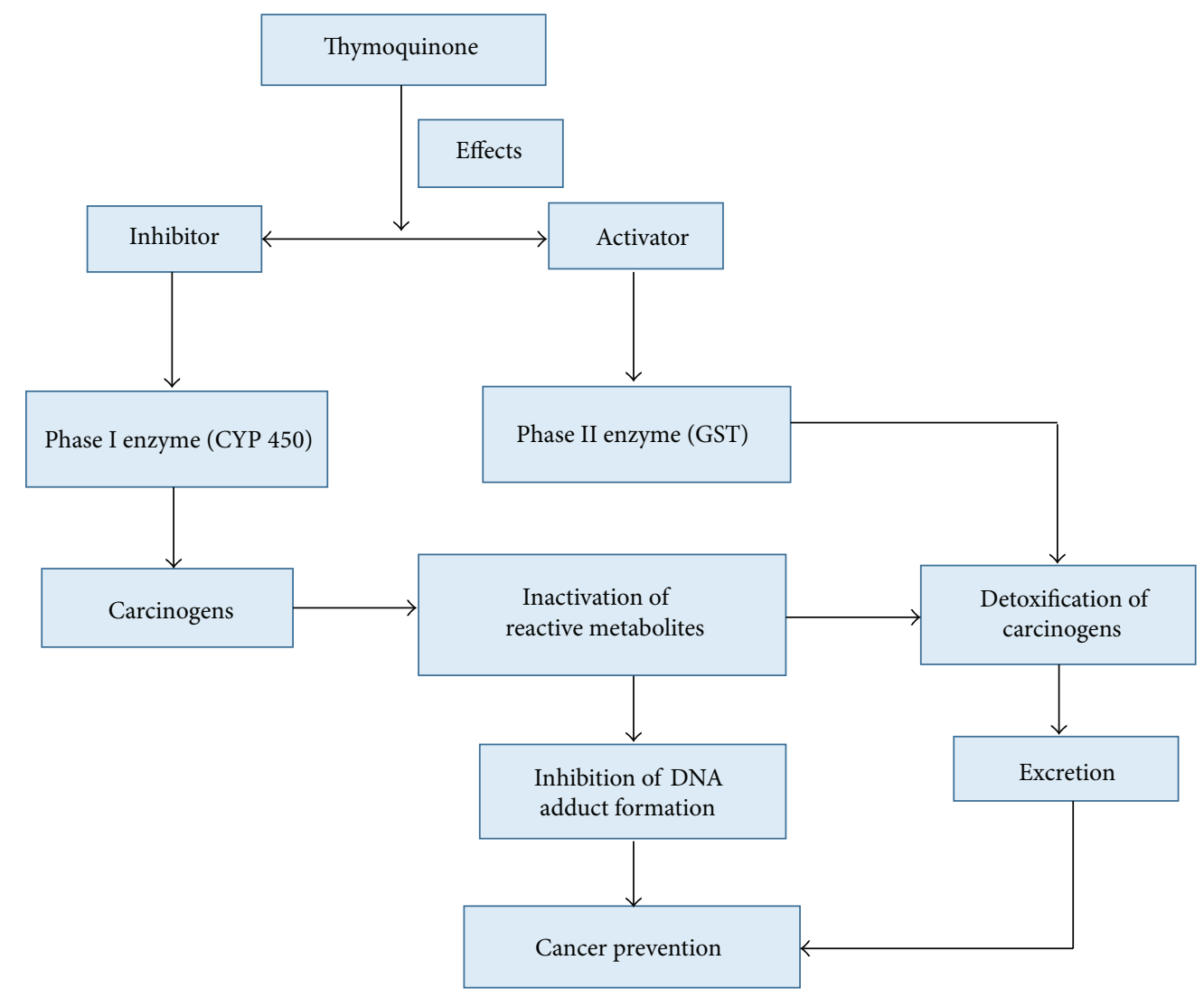

FIgURE 4: Thymoquinone shows a vital role in prevention of cancer via modulation of phase I and phase II enzymes.

$2600 \mathrm{mg} /$ day [157]. A study conducted a randomized, doubleblind, and placebo-controlled trial to check the efficacy of oral $N$. sativa (NS) seed extract supplement in patients with mild hypertension (HT) and results suggest that the daily use of NS seed extract for 2 months may have a blood pressurelowering effect in patients with mild HT [158]. Another report showed that $N$. sativa powder administered to the hypercholesterolemia patients for two months was found to reduce the total cholesterol and triglycerides [159].

As per clinical trials based study on cancer patients, a few studies have been performed to check the efficacy of black seed and their constituents in cancer. The experimental study of animal model showed that dose and efficacy of TQ in disease management are with no toxic effect. Clinical trial based study is needed to confirm the efficacy in cancer control through multitargets activity of various genes.

\section{Conclusions}

Cancer is a major health problem worldwide and also a notorious killer disease in both men and women. Chemotherapy/radiotherapy is the current mode of treatment that exhibits adverse side effect. $N$. sativa may constitute a good therapeutic approach in the prevention of cancer through regulation of molecular process. This review highlights the therapeutic role of $N$. sativa and its constituent TQ and outlines their mechanism in the prevention of cancer through the inactivation or activation of multiple molecular pathways. The molecular features of $N$. sativa combined with other properties are the mainstay in the management of cancer.

\section{Conflict of Interests}

The authors declare that there is no conflict of interests regarding the publication of this paper.

\section{References}

[1] M. M. A. Rizvi, M. S. Alam, S. J. Mehdi, A. Ali, and S. Batra, "Allelic loss of 10q23.3, the PTEN gene locus in cervical carcinoma from Northern Indian population," Pathology and Oncology Research, vol. 18, no. 2, pp. 309-313, 2012.

[2] A. H. Rahmani, M. Alzohairy, A. Y. Y. Babiker, A. A. Khan, S. M. Aly, and M. A. Rizvi, "Implication of androgen receptor in urinary bladder cancer: a critical mini review," International Journal of Molecular Epidemiology and Genetics, vol. 4, no. 3, pp. 150-155, 2013.

[3] M. S. Alam, A. Ali, S. J. Mehdi et al., "HPV typing and its relation with apoptosis in cervical carcinoma from Indian population," Tumor Biology, vol. 33, no. 1, pp. 17-22, 2012.

[4] A. Rahmani, M. Alzohairy, A. K. Mandal, and M. A. Rizvi, "Expressional evaluation of androgen receptor in transitional cell carcinoma of urinary bladder patients," British Journal of Medicine and Medical Research, vol. 1, no. 4, pp. 233-238, 2011. 
[5] A. Y. Babiker, F. M. Eltom, M. S. Abdalaziz, A. Rahmani, S. Abusail, and H. G. Ahmed, "Screening for high risk human papilloma virus (HR-HPV) subtypes, among Sudanese patients with oral lesions," International Journal of Clinical and Experimental Medicine, vol. 6, no. 4, pp. 275-281, 2013.

[6] N. S. Alyasiri, S. J. Mehdi, M. S. Alam et al., "PTEN-mediated AKT activation contributes to the reduced apoptosis among Indian oral squamous cell carcinoma patients," Journal of Cancer Research and Clinical Oncology, vol. 138, no. 1, pp. 103109, 2012.

[7] M. M. A. Rizvi, M. S. Alam, A. Ali, S. J. Mehdi, S. Batra, and A. K. Mandal, "Aberrant promoter methylation and inactivation of PTEN gene in cervical carcinoma from Indian population," Journal of Cancer Research and Clinical Oncology, vol. 137, no. 8, pp. 1255-1262, 2011.

[8] L. Reddy, B. Odhav, and K. D. Bhoola, "Natural products for cancer prevention: a global perspective," Pharmacology and Therapeutics, vol. 99, no. 1, pp. 1-13, 2003.

[9] V. Benetou, P. Orfanos, P. Lagiou, D. Trichopoulos, P. Boffetta, and A. Trichopoulou, "Vegetables and fruits in relation to cancer risk: evidence from the Greek EPIC cohort study," Cancer Epidemiology Biomarkers and Prevention, vol. 17, no. 2, pp. 387-392, 2008.

[10] N. D. Freedman, Y. Park, A. F. Subar et al., "Fruit and vegetable intake and head and neck cancer risk in a large United States prospective cohort study," International Journal of Cancer, vol. 122, no. 10, pp. 2330-2336, 2008.

[11] M. Al-Bukhari, "Division 71 on medicine," in Sahi Al-Bukhari, the Collection of Authentic Sayings of Prophet Mohammad(Peace Be Upon Him), Hilal Yayinlari, Ankara, Turkey, 2nd edition, 1976.

[12] C. M. Kaefer and J. A. Milner, "The role of herbs and spices in cancer prevention," Journal of Nutritional Biochemistry, vol. 19, no. 6, pp. 347-361, 2008.

[13] K. A. Steinmetz and J. D. Potter, "Vegetables, fruit, and cancer prevention: a review," Journal of the American Dietetic Association, vol. 96, no. 10, pp. 1027-1039, 1996.

[14] K. Imai, K. Suga, and K. Nakachi, "Cancer-preventive effects of drinking green tea among a Japanese population," Preventive Medicine, vol. 26, no. 6, pp. 769-775, 1997.

[15] M. J. Messina, V. Persky, K. D. R. Setchell, and S. Barnes, "Soy intake and cancer risk: a review of the in vitro and in vivo data," Nutrition and Cancer, vol. 21, no. 2, pp. 113-131, 1994.

[16] Y. H. Aldebasi, S. M. Aly, and A. H. Rahmani, "Therapeutic implications of curcumin in the prevention of diabetic retinopathy via modulation of anti-oxidant activity and genetic pathways," International Journal of Physiology, Pathophysiology and Pharmacology, vol. 5, no. 4, pp. 203-215, 2013.

[17] M. L. Mathur, J. Gaur, R. Sharma, and K. R. Haldiya, "Antidiabetic properties of a spice plant Nigella sativa," Journal of Endocrinology and Metabolism, vol. 1, no. 1, pp. 1-8, 2011.

[18] A. J. A. Hmza, M. T. Osman, A. Adnan, and E. Omar, "Immunomodulatory effect of Nigella sativa oil in the disease process of type 1 diabetic rats," Research Journal of Pharmaceutical, Biological and Chemical Sciences, vol. 4, pp. 980-988, 2013.

[19] A. Najmi, S. F. Haque, M. Naseeruddin, and R. A. Khan, "Effect of Nigella sativa oil on various clinical and biochemical parameters of metabolic syndrome," International Journal of Diabetes and Metabolism, vol. 16, no. 2, pp. 85-87, 2008.
[20] S. Padhye, S. Banerjee, A. Ahmad, R. Mohammad, and F. H. Sarkar, "From here to eternity-the secret of Pharaohs: therapeutic potential of black cumin seeds and beyond," Cancer Therapy Journal, vol. 6, pp. 495-510, 2008.

[21] S. Bourgou, R. Ksouri, A. Bellila, I. Skandrani, H. Falleh, and B. Marzouk, "Phenolic composition and biological activities of Tunisian Nigella sativa L. shoots and roots," Comptes RendusBiologies, vol. 331, no. 1, pp. 48-55, 2008.

[22] M. Khader, N. Bresgen, and P. M. Eckl, "Antimutagenic effects of ethanolic extracts from selected Palestinian medicinal plants," Journal of Ethnopharmacology, vol. 127, no. 2, pp. 319-324, 2010.

[23] I. O. Farah and R. A. Begum, "Effect of Nigella sativa (N. Sativa L.) and oxidative stress on the survival pattern of MCF-7 breast cancer cells," Biomedical Sciences Instrumentation, vol. 39, pp. 359-364, 2003.

[24] A. Omar, S. Ghosheh, A. Abdulghani, A. Houdi, and P. A. Crookscor, "High performance liquid chromatographic analysis of the pharmacologically active quinones and related compounds in the oil of the black seed (Nigella sativa L.)," Journal of Pharmaceutical and Biomedical Analysis, vol. 19, no. 5, pp. 757-762, 1999.

[25] M. S. Al-Jassir, "Chemical composition and microflora of black cumin (Nigella sativa L.) seeds growing in Saudi Arabia," Food Chemistry, vol. 45, no. 4, pp. 239-242, 1992.

[26] I. S. Bhatia and K. L. Bajaj, "Tannins in black-plum (Syzygium cumini L.) seeds," Biochemical Journal, vol. 128, no. 1, p. 56, 1972.

[27] H. Chun, D. H. Shin, B. S. Hong, W. D. Cho, H. Y. Cho, and H. C. Yang, "Biochemical properties of polysaccharides from black pepper," Biological and Pharmaceutical Bulletin, vol. 25, no. 9, pp. 1203-1208, 2002.

[28] A. D. Correa, L. Jokl, and R. Carlsson, "Amino acid composition of some Amaranthus sp. grain proteins and of its fractions," Archivos Latinoamericanos de Nutricion, vol. 36, no. 3, pp. 466476, 1986.

[29] A. Atta-ur-Rahman, S. Malik, H. Cun-heng, and J. Clardy, "Isolation and structure determination of nigellicine. A novel alkaloid from the seeds of Nigella sativa," Tetrahedron Letters, vol. 26, no. 23, pp. 2759-2762, 1985.

[30] Y. H. Aldebasi, A. H. Rahmani, A. A. Khan, and S. M. Aly, “The effect of vascular endothelial growth factor in the progression of bladder cancer and diabetic retinopathy," International Journal of Clinical and Experimental Medicine, vol. 6, no. 4, pp. 239-251, 2013.

[31] E. A. Arafa, Q. Zhu, Z. I. Shah et al., "Thymoquinone up-regulates PTEN expression and induces apoptosis in doxorubicin-resistant human breast cancer cells," Mutation Research-Fundamental and Molecular Mechanisms of Mutagenesis, vol. 706, no. 1-2, pp. 28-35, 2011.

[32] C. Sakalar, M. Yuruk, T. Kaya, M. Aytekin, S. Kuk, and H. Canatan, "Pronounced transcriptional regulation of apoptotic and TNF-NF-kappa-B signaling genes during the course of thymoquinone mediated apoptosis in HeLa cells," Molecular and Cellular Biochemistry, vol. 383, no. 1-2, pp. 243-251, 2013.

[33] B. H. Ali and G. Blunden, "Pharmacological and toxicological properties of Nigella sativa," Phytotherapy Research, vol. 17, no. 4, pp. 299-305, 2003.

[34] H. S. El-Abhar, D. M. Abdallah, and S. Saleh, "Gastroprotective activity of Nigella sativa oil and its constituent, thymoquinone, against gastric mucosal injury induced by ischaemia/reperfusion in rats," Journal of Ethnopharmacology, vol. 84, no. 2-3, pp. 251-258, 2003. 
[35] L. A. Mbarek, H. A. Mouse, N. Elabbadi et al., "Anti-tumor properties of blackseed (Nigella sativa L.) extracts," Brazilian Journal of Medical and Biological Research, vol. 40, no. 6, pp. 839-847, 2007.

[36] O. A. Badary, O. A. Al-Shabanah, M. N. Nagi, A. C. Al-Rikabi, and M. M. A. Elmazar, "Inhibition of benzo(a)pyrene-induced forestomach carcinogenesis in mice by thymoquinone," European Journal of Cancer Prevention, vol. 8, no. 5, pp. 435-440, 1999.

[37] E. M. Awad, "In Vitro decreases of the fibrinolytic potential of cultured human fibrosarcoma cell line, HT1080, by Nigella sativa oil," Phytomedicine, vol. 12, no. 1-2, pp. 100-107, 2005.

[38] O. A. Badary and A. M. Gamal El-Din, "Inhibitory effects of thymoquinone against 20-methylcholanthrene-induced fibrosarcoma tumorigenesis," Cancer Detection and Prevention, vol. 25, no. 4, pp. 362-368, 2001.

[39] M. A. Abd El-Aziz, H. A. Hassan, M. H. Mohamed, A. M. A. Meki, S. K. H. Abdel-Ghaffar, and M. R. Hussein, "The biochemical and morphological alterations following administration of melatonin, retinoic acid and Nigella sativa in mammary carcinoma: an animal model," International Journal of Experimental Pathology, vol. 86, no. 6, pp. 383-396, 2005.

[40] S. M. Swamy and B. T. Huat, "Intracellular glutathione depletion and reactive oxygen species generation are important in $\alpha$ hederin-induced apoptosis of P388 cells," Molecular and Cellular Biochemistry, vol. 245, no. 1-2, pp. 127-139, 2003.

[41] N. E. Abdelmeguid, R. Fakhoury, S. M. Kamal, and R. J. Al Wafai, "Effects of Nigella sativa and thymoquinone on biochemical and subcellular changes in pancreatic $\beta$-cells of streptozotocin-induced diabetic rats," Journal of Diabetes, vol. 2, no. 4, pp. 256-266, 2010.

[42] E. I. Salim and S. Fukushima, "Chemopreventive potential of volatile oil from black cumin (Nigella sativa L.) seeds against rat colon carcinogenesis," Nutrition and Cancer, vol. 45, no. 2, pp. 195-202, 2003.

[43] M. Fathy and T. Nikaido, "In Vivo modulation of iNOS pathway in hepatocellular carcinoma by Nigella sativa," Environmental Health and Preventive Medicine, vol. 18, no. 5, pp. 377-385, 2013.

[44] S. Banerjee, A. O. Kaseb, Z. Wang et al., "Antitumor activity of gemcitabine and oxaliplatin is augmented by thymoquinone in pancreatic cancer," Cancer Research, vol. 69, no. 13, pp. 5575$5583,2009$.

[45] M. N. Nagi and H. A. Almakki, "Thymoquinone supplementation induces quinone reductase and glutathione transferase in mice liver: possible role in protection against chemical carcinogenesis and toxicity," Phytotherapy Research, vol. 23, no. 9, pp. 1295-1298, 2009.

[46] N. J. Salomi, S. C. Nair, K. K. Jayawardhanan, C. D. Varghese, and K. R. Panikkar, "Antitumour principles from Nigella sativa seeds," Cancer Letters, vol. 63, no. 1, pp. 41-46, 1992.

[47] M. J. Salomi, S. C. Nair, and K. R. Panikkar, "Inhibitory effects of Nigella sativa and saffron (Crocus sativus) on chemical carcinogenesis in mice," Nutrition and Cancer, vol. 16, no. 1, pp. 67-72, 1991.

[48] K. Chaieb, B. Kouidhi, H. Jrah, K. Mahdouani, and A. Bakhrouf, "Antibacterial activity of Thymoquinone, an active principle of Nigella sativa and its potency to prevent bacterial biofilm formation," BMC Complementary and Alternative Medicine, vol. 11, p. 29, 2011.

[49] E. Halawani, "Antibacterial activity of thymoquinone and thymohydroquinone of Nigella sativa L. and their interaction with some antibiotics," Advances in Biological Research, vol. 3, pp. 148-152, 2009.

[50] A. A. Al-Majed, F. A. Al-Omar, and M. N. Nagi, "Neuroprotective effects of thymoquinone against transient forebrain ischemia in the rat hippocampus," European Journal of Pharmacology, vol. 543, no. 1-3, pp. 40-47, 2006.

[51] D. R. Worthen, O. A. Ghosheh, and P. A. Crooks, "The in vitro anti-tumor activity of some crude and purified components of blackseed, Nigella sativa L.," Anticancer Research A, vol. 18, no. 3, pp. 1527-1532, 1998.

[52] M. N. Nagi and M. A. Mansour, "Protective effect of thymoquinone against doxorubicin-induced cardiotoxicity in rats: a possible mechanism of protection," Pharmacological Research, vol. 41, no. 3, pp. 283-289, 2000.

[53] T. Maehama and J. E. Dixon, "The tumor suppressor, PTEN/MMACl, dephosphorylates the lipid second messenger, phosphatidylinositol 3,4,5-trisphosphate," Journal of Biological Chemistry, vol. 273, no. 22, pp. 13375-13378, 1998.

[54] A. Rahmani, M. Alzohairy, A. Y. Babiker, M. A. Rizvi, and H. D. Elkarimahmad, "Clinicopathological significance of PTEN and bcl2 expressions in oral squamous cell carcinoma," International Journal of Clinical and Experimental Pathology, vol. 5, no. 9, pp. 965-971, 2012.

[55] H. Gali-Muhtasib, M. Diab-Assaf, C. Boltze et al., "Thymoquinone extracted from black seed triggers apoptotic cell death in human colorectal cancer cells via a p53-dependent mechanism," International Journal of Oncology, vol. 25, no. 4, pp. 857-866, 2004.

[56] H. Gali-Muhtasib, D. Kuester, C. Mawrin et al., “Thymoquinone triggers inactivation of the stress response pathway sensor CHEK1 and contributes to apoptosis in colorectal cancer cells," Cancer Research, vol. 68, no. 14, pp. 5609-5618, 2008.

[57] A. L. Gartel, M. S. Serfas, and A. L. Tyner, "p21-Negative regulator of the cell cycle," Proceedings of the Society for Experimental Biology and Medicine, vol. 213, no. 2, pp. 138-149, 1996.

[58] A. L. Gartel and A. L. Tyner, "The growth-regulatory role of p21 (WAF1/CIP1)," Progress in Molecular and Subcellular Biology, vol. 20, pp. 43-71, 1998.

[59] M. A. El-Mahdy, Q. Zhu, Q. Wang, G. Wani, and A. A. Wani, "Thymoquinone induces apoptosis through activation of caspase- 8 and mitochondrial events in p53-null myeloblastic leukemia HL-60 cells," International Journal of Cancer, vol. 117, no. 3, pp. 409-417, 2005.

[60] R. Huovinen, A. Warri, and Y. Collan, "Mitotic activity, apoptosis and TRPM-2 mRNA expression in DMBA-induced rat mammary carcinoma treated with anti-estrogen toremifene," International Journal of Cancer, vol. 55, no. 4, pp. 685-691, 1993.

[61] K. Hollowood and J. C. Macartney, "Reduced apoptotic cell death in follicular lymphoma," Journal of Pathology, vol. 163, no. 4, pp. 337-342, 1991.

[62] E. H. Jo, H. D. Hong, N. C. Ahn et al., "Modulations of the Bcl-2/Bax family were involved in the chemopreventive effects of licorice root (Glycyrrhiza uralensis Fisch) in MCF-7 human breast cancer cell," Journal of Agricultural and Food Chemistry, vol. 52, no. 6, pp. 1715-1719, 2004.

[63] C. Chirathaworn, W. Kongcharoensuntorn, T. Dechdoungchan, A. Lowanitchapat, P. Sa-nguanmoo, and Y. Poovorawan, "Myristica fragrans Houtt. methanolic extract induces apoptosis in a human leukemia cell line through SIRT1 mRNA downregulation," Journal of the Medical Association of Thailand, vol. 90, no. 11, pp. 2422-2428, 2007. 
[64] M. A. Khan, H. Chen, M. Tania, and D. Zhang, "Anticancer activities of Nigella sativa (Black Cumin)," The African Journal of Traditional, Complementary and Alternative Medicines, vol. 8, pp. 226-232, 2011.

[65] A. R. Hussain, M. Ahmed, S. Ahmaed et al., "Thymoquinone suppresses growth and induces apoptosis via generation of reactive oxygen species in primary effusion lymphoma," Free Radical Biology \& Medicine, vol. 50, no. 8, pp. 978-987, 2011.

[66] S. Rooney and M. F. Ryan, "Modes of action of alpha-hederin and thymoquinone, active constituents of Nigella sativa, against HEp-2 cancer cells," Anticancer Research B, vol. 25, no. 6, pp. 4255-4259, 2005.

[67] H. U. Gali-Muhtasib, W. G. Abou Kheir, L. A. Kheir, N. Darwiche, and P. A. Crooks, "Molecular pathway for thymoquinone-induced cell-cycle arrest and apoptosis in neoplastic keratinocytes," Anti-Cancer Drugs, vol. 15, no. 4, pp. 389399, 2004.

[68] K. Effenberger, S. Breyer, and R. Schobert, “Terpene conjugates of the Nigella sativa seed-oil constituent thymoquinone with enhanced efficacy in cancer cells," Chemistry \& Biodiversity, vol. 7, no. 1, pp. 129-139, 2010.

[69] C. C. Woo, A. P. Kumar, G. Sethi, and K. H. B. Tan, “Thymoquinone: potential cure for inflammatory disorders and cancer," Biochemical Pharmacology, vol. 83, no. 4, pp. 443-451, 2012.

[70] A. Samali, H. Nordgren, B. Zhivotovsky, E. Peterson, and S. Orrenius, "A comparative study of apoptosis and necrosis in HepG2 cells: oxidant-induced caspase inactivation leads to necrosis," Biochemical and Biophysical Research Communications, vol. 255, no. 1, pp. 6-11, 1999.

[71] M. N. Nagi, H. A. Almakki, M. M. Sayed-Ahmed, and A. M. Al-Bekairi, "Thymoquinone supplementation reverses acetaminophen-induced oxidative stress, nitric oxide production and energy decline in mice liver," Food and Chemical Toxicology, vol. 48, no. 8-9, pp. 2361-2365, 2010.

[72] O. A. Badary, R. A. Taha, A. M. Gamal El-Din, and M. H. Abdel-Wahab, "Thymoquinone is a potent superoxide anion scavenger," Drug and Chemical Toxicology, vol. 26, no. 2, pp. 8798, 2003.

[73] A. M. Fouda, M. Y. Daba, G. M. Dahab, and O. A. Sharaf ElDin, "Thymoquinone ameliorates renal oxidative damage and proliferative response induced by mercuric chloride in rats," Basic and Clinical Pharmacology and Toxicology, vol. 103, no. 2, pp. 109-118, 2008.

[74] A. El-Mahmoudy, H. Matsuyama, M. A. Borgan et al., "Thymoquinone suppresses expression of inducible nitric oxide synthase in rat macrophages," International Immunopharmacology, vol. 2, no. 11, pp. 1603-1611, 2002.

[75] G. Sethi, S. A. Kwang, and B. B. Aggarwal, "Targeting nuclear factor- $\kappa \mathrm{B}$ activation pathway by thymoquinone: role in suppression of antiapoptotic gene products and enhancement of apoptosis," Molecular Cancer Research, vol. 6, no. 6, pp. 10591070, 2008.

[76] Y. J. Huang, W. X. Qi, A. N. He, Y. J. Sun, Z. Shen, and Y. Yao, "Prognostic value of tissue vascular endothelial growth factor expression in bladder cancer: a meta-analysis," Asian Pacific Journal of Cancer Prevention, vol. 14, no. 2, pp. 645-649, 2013.

[77] J. Adams, P. J. Carder, S. Downey et al., "Vascular endothelial growth factor (VEGF) in breast cancer: comparison of plasma, serum, and tissue VEGF and microvessel density and effects of tamoxifen," Cancer Research, vol. 60, no. 11, pp. 2898-2905, 2000 .
[78] C. H. Shih, S. Ozawa, N. Ando, M. Ueda, and M. Kitajima, "Vascular endothelial growth factor expression predicts outcome and lymph node metastasis in squamous cell carcinoma of the esophagus," Clinical Cancer Research, vol. 6, no. 3, pp. 1161-1168, 2000.

[79] H. Mineta, K. Miura, T. Ogino et al., "Prognostic value of vascular endothelial growth factor (VEGF) in head and neck squamous cell carcinomas," British Journal of Cancer, vol. 83, no. 6, pp. 775-781, 2000.

[80] T. Yi, S. Cho, Z. Yi et al., "Thymoquinone inhibits tumor angiogenesis and tumor growth through suppressing AKT and extracellular signal-regulated kinase signaling pathways," Molecular Cancer Therapeutics, vol. 7, no. 7, pp. 1789-1796, 2008.

[81] W. Asfour, S. Almadi, and L. Haffar, “Thymoquinone suppresses cellular proliferation, inhibits VEGF production and obstructs tumor progression and invasion in the rat model of DMHinduced colon carcinogenesis," Pharmacology \& Pharmacy, vol. 4, no. 1, pp. 7-17, 2013.

[82] L. Peng, A. Liu, Y. Shen et al., "Antitumor and anti-angiogenesis effects of thymoquinone on osteosarcoma through the NF- $\kappa \mathrm{B}$ pathway," Oncology Reports, vol. 29, no. 2, pp. 571-578, 2013.

[83] S. Rajput, B. N. P. Kumar, S. Sarkar et al., "Targeted apoptotic effects of thymoquinone and tamoxifen on XIAP mediated Akt regulation in breast cancer," PLoS ONE, vol. 8, Article ID e61342, 2013.

[84] L. An, W. Wu, C. Zhao, and W. Zhi-hao, "Anti-angiogenic effect of thymoquinone on angiogenesis and proliferation of pancreatic cancer," Chinese Journal of Pathophysiology, vol. 27, pp. 2281-2285, 2011.

[85] L. Minghetti, "Cyclooxygenase-2 (COX-2) in inflammatory and degenerative brain diseases," Journal of Neuropathology and Experimental Neurology, vol. 63, no. 9, pp. 901-910, 2004.

[86] R. G. Ramsay, D. Ciznadija, M. Vanevski, and T. Mantamadiotis, "Transcriptional regulation of cyclo-oxygenase expression: three pillars of control," International Journal of Immunopathology and Pharmacology, vol. 16, no. 2, pp. 59-67, 2003.

[87] B. Singh, J. A. Berry, A. Shoher, V. Ramakrishnan, and A. Lucci, "COX-2 overexpression increases motility and invasion of breast cancer cells," International Journal of Oncology, vol. 26, no. 5, pp. 1393-1399, 2005.

[88] F. R. Khuri, H. Wu, J. J. Lee et al., "Cyclooxygenase-2 overexpression is a marker of poor prognosis in stage I non-small cell lung cancer," Clinical Cancer Research, vol. 7, no. 4, pp. 861-867, 2001.

[89] S. Cascinu, M. Scartozzi, G. Carbonari et al., "COX-2 and NF-KB overexpression is common in pancreatic cancer but does not predict for COX-2 inhibitors activity in combination with gemcitabine and oxaliplatin," American Journal of Clinical Oncology: Cancer Clinical Trials, vol. 30, no. 5, pp. 526-530, 2007.

[90] E. Richardsen, R. D. Uglehus, J. Due, C. Busch, and L. Busund, "COX-2 is overexpressed in primary prostate cancer with metastatic potential and may predict survival. A comparison study between COX-2, TGF- $\beta$, IL-10 and Ki67," Cancer Epidemiology, vol. 34, no. 3, pp. 316-322, 2010.

[91] C. Costa, R. Soares, J. S. Reis-Filho, D. Leitão, I. Amendoeira, and F. C. Schmitt, "Cyclo-oxygenase 2 expression is associated with angiogenesis and lymph node metastasis in human breast cancer," Journal of Clinical Pathology, vol. 55, no. 6, pp. 429-434, 2002.

[92] S. M. Yu and S. J. Kim, "Thymoquinone (TQ) regulates cyclooxygenase-2 expression and prostaglandin E2 production 
through PI3kinase (PI3K)/p38 kinase pathway in human breast cancer cell line, MDA-MB-231," Animal Cells and Systems, vol. 16, no. 4, pp. 274-279, 2012.

[93] R. El Mezayen, M. El Gazzar, M. R. Nicolls, J. C. Marecki, S. C. Dreskin, and H. Nomiyama, "Effect of thymoquinone on cyclooxygenase expression and prostaglandin production in a mouse model of allergic airway inflammation," Immunology Letters, vol. 106, no. 1, pp. 72-81, 2006.

[94] P. A. Baeuerle and T. Henkel, "Function and activation of NF$\kappa \mathrm{B}$ in the immune system," Annual Review of Immunology, vol. 12, pp. 141-179, 1994.

[95] S. Miyamoto and I. M. Verma, "Rel/NF- $\kappa \mathrm{B} / \mathrm{I} \kappa \mathrm{B}$ story," Advances in Cancer Research, vol. 66, pp. 255-292, 1995.

[96] H. L. Pahl, "Activators and target genes of Rel/NF- $\kappa$ B transcription factors," Oncogene, vol. 18, no. 49, pp. 6853-6866, 1999.

[97] Z. Yan, K. Subbaramaiah, T. Camilli et al., "Benzo[a]pyrene induces the transcription of cyclooxygenase- 2 in vascular smooth muscle cells. Evidence for the involvement of extracellular signal- regulated kinase and NF- $\kappa$ B," Journal of Biological Chemistry, vol. 275, no. 7, pp. 4949-4955, 2000.

[98] N. Rioux and A. Castonguay, "The induction of cyclooxygenase1 by a tobacco carcinogen inU937 human macrophages is correlated to the activation of NF- $\kappa \mathrm{B}$," Carcinogenesis, vol. 21 , no. 9, pp. 1745-1751, 2000.

[99] N. Li and M. Karin, "Ionizing radiation and short wavelength UV activate NF- $\kappa$ B through two distinct mechanisms," Proceedings of the National Academy of Sciences of the United States of America, vol. 95, no. 22, pp. 13012-13017, 1998.

[100] P. A. Baeuerle, M. Lenardo, J. W. Pierce, and D. Baltimore, "Phorbol-ester-induced activation of the NF- $\kappa$ B transcription factor involves dissociation of an apparently cytoplasmic NF$\kappa \mathrm{B} /$ inhibitor complex," Cold Spring Harbor Symposia on Quantitative Biology, vol. 53, no. 2, pp. 789-798, 1988.

[101] S. M. Yu and S. J. Kim, "Thymoquinone-induced reactive oxygen species causes apoptosis of chondrocytes via PI3K/Akt and p38kinase pathway," Experimental Biology and Medicine, vol. 238, pp. 811-820, 2013.

[102] N. M. Chandler, J. J. Canete, and M. P. Callery, "Increased expression of NF- $\kappa$ B subunits in human pancreatic cancer cells," Journal of Surgical Research, vol. 118, no. 1, pp. 9-14, 2004.

[103] S. Liptay, C. K. Weber, L. Ludwig, M. Wagner, G. Adler, and R. M. Schmid, "Mitogenic and antiapoptotic role of constitutive NF- $\kappa \mathrm{B} /$ Rel activity in pancreatic cancer," International Journal of Cancer, vol. 105, no. 6, pp. 735-746, 2003.

[104] W. Wang, J. L. Abbruzzese, D. B. Evans, L. Larry, K. R. Cleary, and P. J. Chiao, "The nuclear factor- $\kappa \mathrm{B}$ RelA transcription factor is constitutively activated in human pancreatic adenocarcinoma cells," Clinical Cancer Research, vol. 5, no. 1, pp. 119-127, 1999.

[105] N. Chehl, G. Chipitsyna, Q. Gong, C. J. Yeo, and H. A. Arafat, "Anti-inflammatory effects of the Nigella sativa seed extract, thymoquinone, in pancreatic cancer cells," $H P B$, vol. 11, no. 5, pp. 373-381, 2009.

[106] H. Q. Mu, S. Yang, Y. J. Wang, and Y. H. Chen, "Role of NF- $\kappa$ B in the anti-tumor effect of thymoquinone on bladder cancer," Zhonghua Yi Xue Za Zhi, vol. 92, no. 6, pp. 392-396, 2012.

[107] Z. Wu, Z. Chen, Y. Shen, L. Huang, and P. Jiang, "Anti-metastasis effect of thymoquinone on human pancreatic cancer," Yaoxue Xuebao, vol. 46, no. 8, pp. 910-914, 2011.

[108] G. Jenster, "The role of the androgen receptor in the development and progression of prostate cancer," Seminars in Oncology, vol. 26, no. 4, pp. 407-421, 1999.
[109] S. Murthy, M. Wu, V. U. Bai et al., "Role of androgen receptor in progression of LNCaP prostate cancer cells from G1 to S phase," PLoS ONE, vol. 8, no. 2, Article ID e56692, 2013.

[110] V. U. Bai, E. Cifuentes, M. Menon, E. R. Barrack, and G. P. Reddy, "Androgen receptor regulates Cdc6 in synchronized LNCaP cells progressing from G1 to S phase," Journal of Cellular Physiology, vol. 204, no. 2, pp. 381-387, 2005.

[111] E. Cifuentes, R. Croxen, M. Menon, E. R. Barrack, and G. P. Reddy, "Synchronized prostate cancer cells for studying androgen regulated events in cell cycle progression from G1 into S phase," Journal of Cellular Physiology, vol. 195, no. 3, pp. 337345, 2003.

[112] V. Kuenen-Boumeester, T. H. Van Der Kwast, W. L. J. Van Putten, C. Claassen, B. Van Ooijen, and S. C. Henzen-Logmans, "Immunohistochemical determination of androgen receptors in relation to oestrogen and progesterone receptors in female breast cancer," International Journal of Cancer, vol. 52, no. 4, pp. 581-584, 1992.

[113] B. J. Feldman and D. Feldman, "The development of androgenindependent prostate cancer," Nature Reviews Cancer, vol. 1, no. 1, pp. 34-45, 2001.

[114] H. Miyamoto, E. M. Messing, and C. Chang, "Androgen deprivation therapy for prostate cancer: current status and future prospects," Prostate, vol. 61, no. 4, pp. 332-353, 2004.

[115] D. P. Petrylak, M. R. Smith, and M. A. Carducci, "The current role of chemotherapy in metastatic hormone-refractory prostate cancer," Urology, vol. 65, no. 5, pp. 3-8, 2005.

[116] A. O. Kaseb, K. Chinnakannu, D. Chen et al., "Androgen receptor- and E2F-1-targeted thymoquinone therapy for hormone-refractory prostate cancer," Cancer Research, vol. 67, no. 16, pp. 7782-7788, 2007.

[117] B. Samuelsson, S.-E. Dahlen, and J. A. Lindgren, "Leukotrienes and lipoxins: structures, biosynthesis, and biological effects," Science, vol. 237, no. 4819, pp. 1171-1176, 1987.

[118] P. Needleman, J. Turk, and B. A. Jakschik, "Arachidonic acid metabolism," Annual Review of Biochemistry, vol. 55, pp. 69-102, 1986.

[119] R. A. Lewis, K. F. Austen, and R. J. Soberman, "Leukotrienes and other products of the 5-lipoxygenase pathway. Biochemistry and relation to pathobiology in human diseases," New England Journal of Medicine, vol. 323, no. 10, pp. 645-655, 1990.

[120] R. Yoshimura, M. Matsuyama, M. Mitsuhashi et al., "Relationship between lipoxygenase and human testicular cancer," International Journal of Molecular Medicine, vol. 13, no. 3, pp. 389-393, 2004.

[121] M. Matsuyama, R. Yoshimura, M. Mitsuhashi et al., "Expression of lipoxygenase in human prostate cancer and growth reduction by its inhibitors," International Journal of Oncology, vol. 24, no. 4, pp. 821-827, 2004.

[122] W. G. Jiang, A. Douglas-Jones, and R. E. Mansel, "Levels of expression of lipoxygenases and cyclooxygenase-2 in human breast cancer," Prostaglandins Leukotrienes and Essential Fatty Acids, vol. 69, no. 4, pp. 275-281, 2003.

[123] M. T. Yip-Schneider, D. S. Barnard, S. D. Billings et al., "Cyclooxygenase-2 expression in human pancreatic adenocarcinomas," Carcinogenesis, vol. 21, no. 2, pp. 139-146, 2000.

[124] M. Mansour and S. Tornhamre, "Inhibition of 5-lipoxygenase and leukotriene $\mathrm{C} 4$ synthase in human blood cells by thymoquinone," Journal of Enzyme Inhibition and Medicinal Chemistry, vol. 19, no. 5, pp. 431-436, 2004. 
[125] J. Bromberg and J. E. Darnell Jr., "The role of STATs in transcriptional control and their impact on cellular function," Oncogene, vol. 19, no. 21, pp. 2468-2473, 2000.

[126] C. I. Santos and A. P. Costa-Pereira, "Signal transducers and activators of transcription-from cytokine signalling to cancer biology," Biochimica et Biophysica Acta-Reviews on Cancer, vol. 1816, no. 1, pp. 38-49, 2011.

[127] G. Badr, M. Mohany, and F. Abu-Tarboush, "Thymoquinone decreases F-actin polymerization and the proliferation of human multiple myeloma cells by suppressing STAT3 phosphorylation and Bcl2/Bcl-XL expression," Lipids in Health and Disease, vol. 10, p. 236, 2011.

[128] F. Li, P. Rajendran, and G. Sethi, “Thymoquinone inhibits proliferation, induces apoptosis and chemosensitizes human multiple myeloma cells through suppression of signal transducer and activator of transcription 3 activation pathway," British Journal of Pharmacology, vol. 161, no. 3, pp. 541-554, 2010.

[129] F. I. Al-Jenoobi, A. A. Al-Thukair, F. A. Abbas et al., "Effect of black seed on dextromethorphan o- and n-demethylation in human liver microsomes and healthy human subjects," Drug Metabolism Letters, vol. 4, no. 1, pp. 51-55, 2010.

[130] M. N. Nagi, K. Alam, O. A. Badary, O. A. Al-Shabanah, H. A. AlSawaf, and A. M. Al-Bekairi, "Thymoquinone protects against carbon tetrachloride hepatotoxicity in mice via an antioxidant mechanism," Biochemistry and Molecular Biology International, vol. 47, no. 1, pp. 153-159, 1999.

[131] J. N. Feige, L. Gelman, L. Michalik, B. Desvergne, and W. Wahli, "From molecular action to physiological outputs: peroxisome proliferator-activated receptors are nuclear receptors at the crossroads of key cellular functions," Progress in Lipid Research, vol. 45, no. 2, pp. 120-159, 2006.

[132] D. J. Mangelsdorf, C. Thummel, M. Beato et al., "The nuclear receptor super-family: the second decade," Cell, vol. 83 , no. 6 , pp. 835-839, 1995.

[133] A. P. Kumar, A. L. Quake, M. K. X. Chang et al., "Repression of NHE1 expression by PPAR $\gamma$ activation is a potential new approach for specific inhibition of the growth of tumor cells in vitro and in vivo," Cancer Research, vol. 69, no. 22, pp. 86368644, 2009.

[134] G. Venkatachalam, A. P. Kumar, L. S. Yue, S. Pervaiz, M. V. Clement, and M. K. Sakharkar, "Computational identification and experimental validation of PPRE motifs in NHE1 and MnSOD genes of human," BMC Genomics, vol. 10, supplement 3, p. S5, 2009.

[135] P. Sarraf, E. Mueller, D. Jones et al., "Differentiation and reversal of malignant changes in colon cancer through PPAR $\gamma$," Nature Medicine, vol. 4, no. 9, pp. 1046-1052, 1998.

[136] T. Kubota, K. Koshizuka, E. A. Williamson et al., "Ligand for peroxisome proliferator-activated receptor $\gamma$ (Troglitazone) has potent antitumor effect against human prostate cancer both in vitro and in vivo," Cancer Research, vol. 58, no. 15, pp. 3344-3352, 1998.

[137] T. H. Chang and E. Szabo, "Induction of differentiation and apoptosis by ligands of peroxisome proliferator-activated receptor $\gamma$ in non-small cell lung cancer," Cancer Research, vol. 60, no. 4, pp. 1129-1138, 2000.

[138] F. Yin, S. Wakino, Z. Liu et al., “Troglitazone inhibits growth of MCF-7 breast carcinoma cells by targeting G1 cell cycle regulators," Biochemical and Biophysical Research Communications, vol. 286, no. 5, pp. 916-922, 2001.

[139] C. C. Woo, S. Y. Loo, V. Gee et al., "Anticancer activity of thymoquinone in breast cancer cells: possible involvement of
PPAR- $\gamma$ pathway," Biochemical Pharmacology, vol. 82, no. 5, pp. 464-475, 2011.

[140] S. M. Qadri, H. Mahmud, M. Föller, and F. Lang, "Thymoquinone-induced suicidal erythrocyte death," Food and Chemical Toxicology, vol. 47, no. 7, pp. 1545-1549, 2009.

[141] O. Badary, O. A. Al-Shabanah, M. N. Nagi, A. M. Al-Bekairi, and M. M. Almazar, "Acute and subchronic toxicity of thymoquinone in mice," Drug Development Research, vol. 44, no. 2-3, pp. 56-61, 1998.

[142] M. Khader, N. Bresgen, and P. M. Eckl, "In Vitro toxicological properties of thymoquinone," Food and Chemical Toxicology, vol. 47, no. 1, pp. 129-133, 2009.

[143] A. Al-Ali, A. A. Alkhawajah, M. A. Randhawa, and N. A. Shaikh, "Oral and intraperitoneal LD50 of thymoquinone, an active principle of Nigella sativa, in mice and rats," Journal of Ayub Medical College, vol. 20, no. 2, pp. 25-27, 2008.

[144] M. A. Mansour, O. T. Ginawi, T. El-Hadiyah, A. S. El-Khatib, O. A. Al-Shabanah, and H. A. Al-Sawaf, "Effects of volatile oil constituents of Nigella sativa on carbon tetrachloride-induced hepatotoxicity in mice: evidence for antioxidant effects of thymoquinone," Research Communications in Molecular Pathology and Pharmacology, vol. 110, no. 3-4, pp. 239-251, 2001.

[145] F. Vaillancourt, P. Silva, Q. Shi, H. Fahmi, J. C. Fernandes, and M. Benderdour, "Elucidation of molecular mechanisms underlying the protective effects of thymoquinone against rheumatoid arthritis," Journal of Cellular Biochemistry, vol. 112, no. 1, pp. 107-117, 2011.

[146] H. M. A. Dollah, S. Parhizkar, L. A. Latiff, and M. H. B. Hassan, "Toxicity effect of Nigella sativa on the liver function of rats," Advanced Pharmaceutical Bulletin, vol. 3, no. 1, pp. 97-102, 2013.

[147] N. Valizadeh, H. R. Zakeri, and A. Shafiee, "The effect of Nigella sativa extract on biochemical bon markers in osteopenic postmenopausal women," Iranian Journal of Endocrinology \& Metabolism, vol. 10, pp. 570-580, 2009.

[148] T. Khanna, F. A. Zaidi, and P. C. Dandiya, "CNS and analgesic studies on Nigella sativa," Fitoterapia, vol. 64, no. 5, pp. 407-410, 1993.

[149] M. H. A. Tissera, M. Chandrika, P. Serasinghe, and R. Tangavelu, Toxicity Study of Kaluduru (Oil of Nigella sativa). "Ayurveda Sameeksha", Department of Ayurveda, Sri Lanka, 1997.

[150] A. Zaoui, Y. Cherrah, N. Mahassini, K. Alaoui, H. Amarouch, and M. Hassar, "Acute and chronic toxicity of Nigella sativa fixed oil," Phytomedicine, vol. 9, no. 1, pp. 69-74, 2002.

[151] S. Banerjee, A. S. Azmi, S. Padhye et al., "Structure-activity studies on therapeutic potential of thymoquinone analogs in pancreatic cancer," Pharmaceutical Research, vol. 27, no. 6, pp. 1146-1158, 2010.

[152] S. Banerjee, S. Padhye, A. Azmi et al., "Review on molecular and therapeutic potential of thymoquinone in cancer," Nutrition and Cancer, vol. 62, no. 7, pp. 938-946, 2010.

[153] K. Effenberger, S. Breyer, and R. Schobert, "Terpene conjugates of the Nigella sativa seed-oil constituent thymoquinone with enhanced efficacy in cancer cells," Chemistry and Biodiversity, vol. 7, no. 1, pp. 129-139, 2010.

[154] J. Yuan, M. Sanhaji, A. Krmer et al., "Polo-box domain inhibitor poloxin activates the spindle assembly checkpoint and inhibits tumor growth in vivo," American Journal of Pathology, vol. 179, no. 4, pp. 2091-2099, 2011.

[155] O. Chahrour, L. Xiangrui, L. Franki, A. Abdullah, C. Midgley, and W. Shudong, Synthesis, Design, and biological evaluation 
of thymoquinone derivatives and ON01910 derivatives as anticancer agents. Abstract in National Cancer Research Institute Conference, B.T. Convention Center.

[156] S. Breyer, K. Effenberger, and R. Schobert, "Effects of thymoquin-one-fattyacid conjugates on cancer cells," ChemMedChem, vol. 4, no. 5, pp. 761-768, 2009.

[157] A. M. Al-Amri and A. O. Bamosa, "Phase I safety and clinical activity study of thymoquinone in patients with advanced refractory malignant disease," Shiraz E-Medical Journal, vol. 10, no. 3, pp. 107-111, 2009.

[158] F. R. Dehkordi and A. F. Kamkhah, "Antihypertensive effect of Nigella sativa seed extract in patients with mild hypertension," Fundamental and Clinical Pharmacology, vol. 22, no. 4, pp. 447$452,2008$.

[159] I. U. Bhatti, F. U. Rehman, M. A. Khan, and S. K. Marwat, "Effect of prophetic medicine kalonji (Nigella sativaL.) on lipid profile of human being: an vivo approach," World Applied Sciences Journal, vol. 6, no. 8, pp. 1053-1057, 2009. 


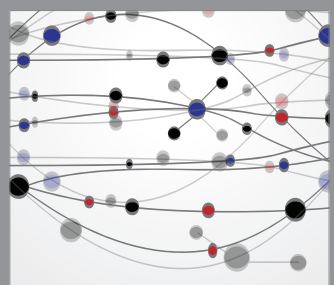

The Scientific World Journal
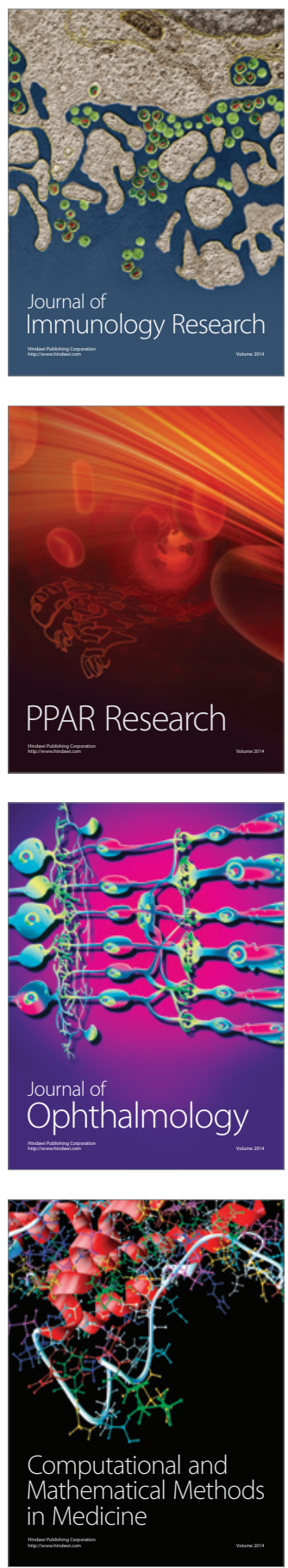

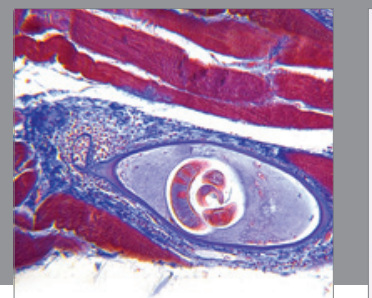

Gastroenterology

Research and Practice
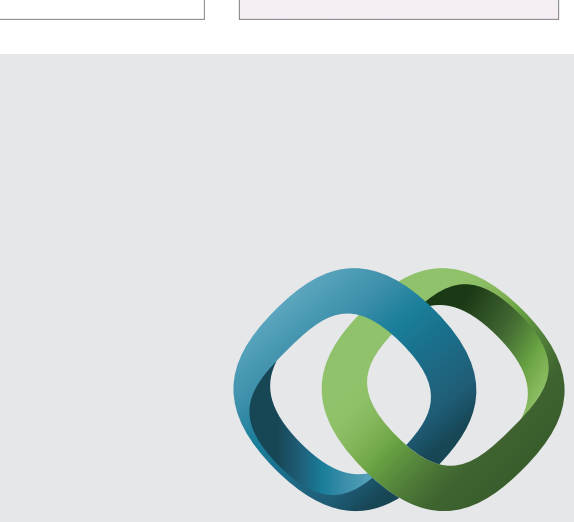

\section{Hindawi}

Submit your manuscripts at

http://www.hindawi.com
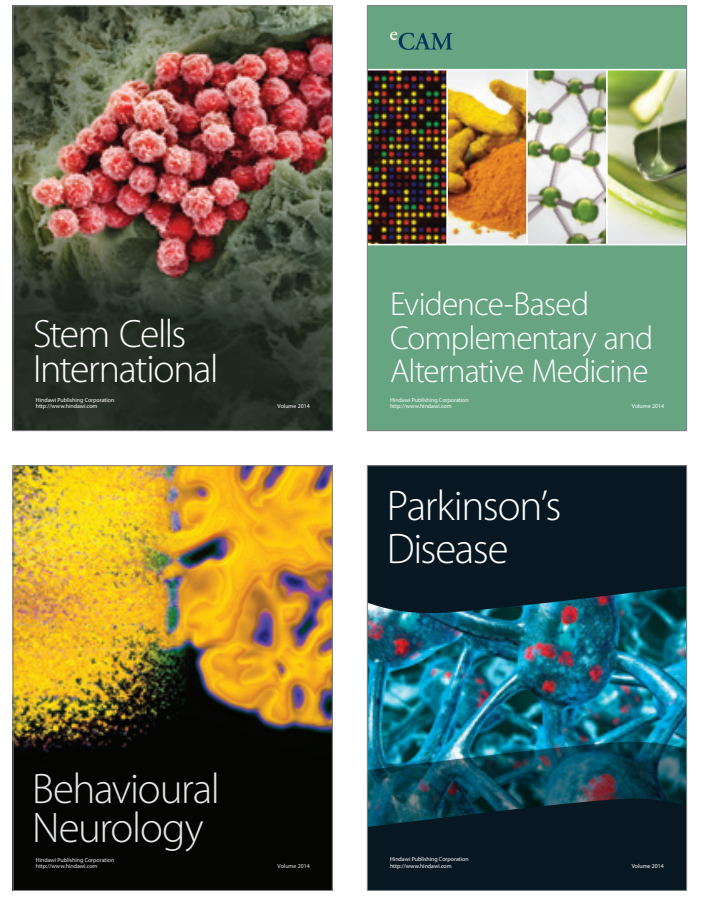
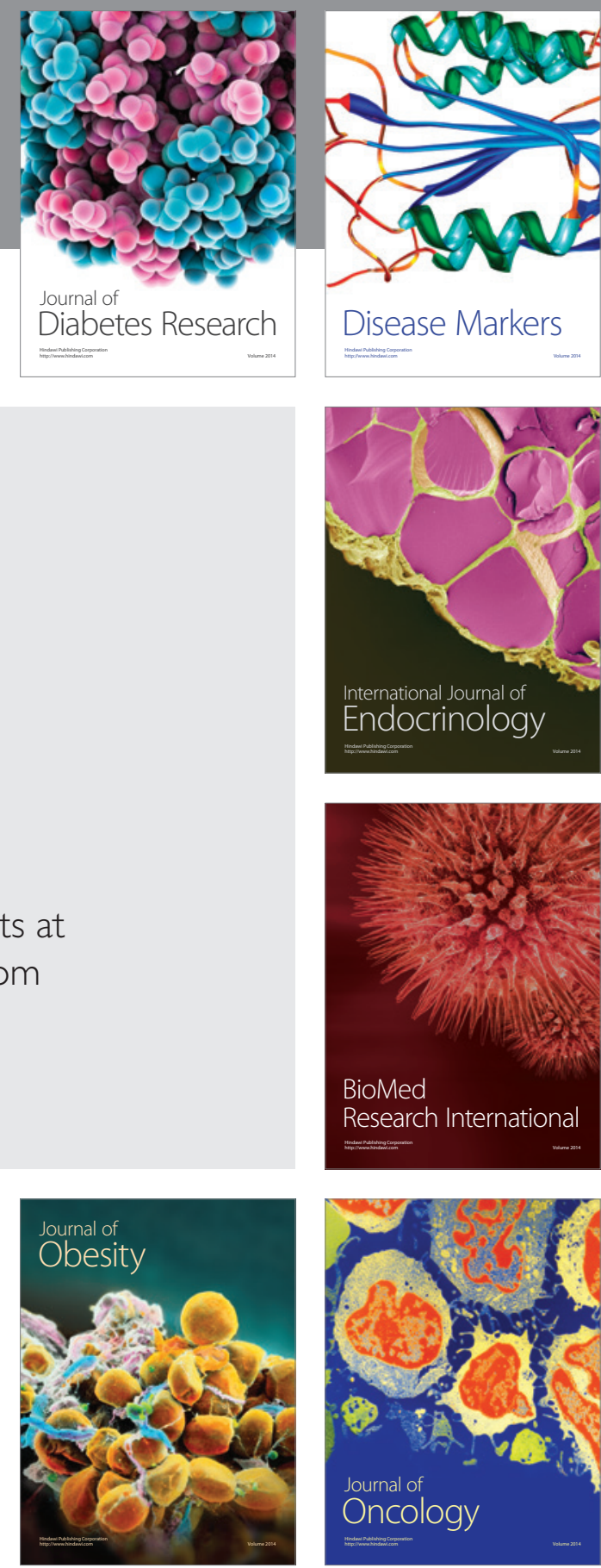

Disease Markers
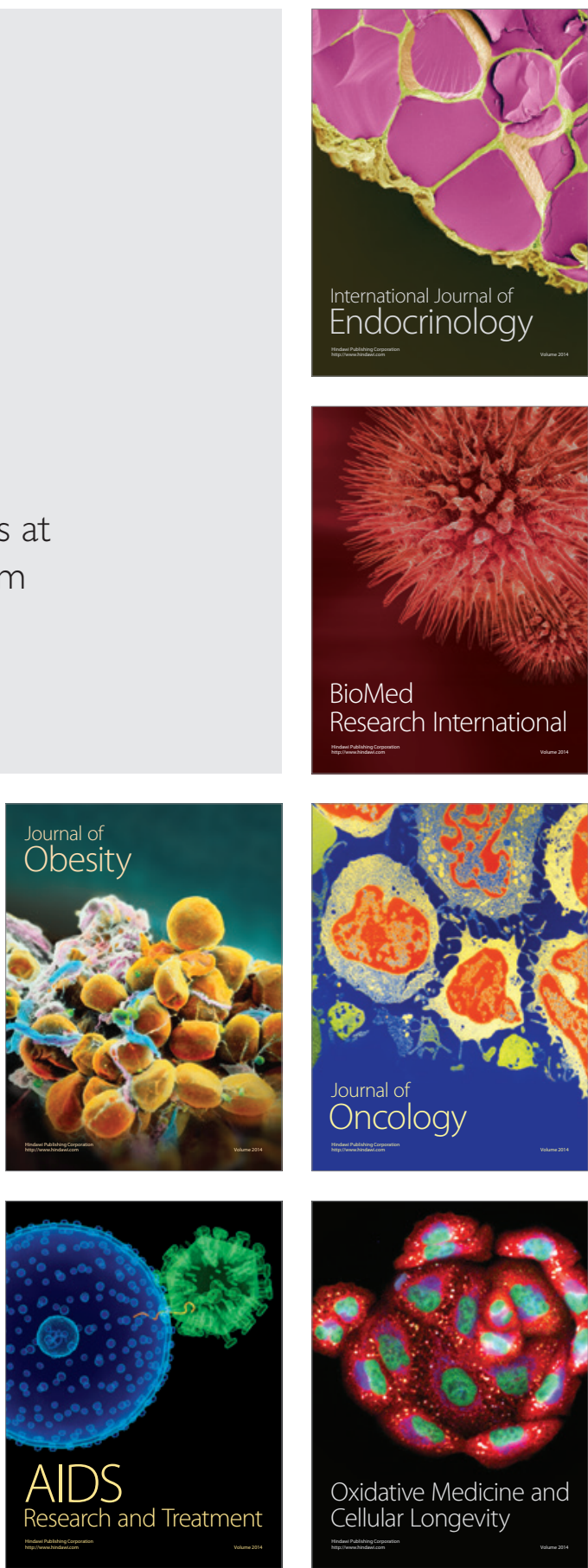